\title{
The Role of Psychological Safety and Psychological Empowerment on Intrapreneurial Behavior towards Successful Individual Performance: A Conceptual Framework
}

\author{
Mahmoud Ahmad Mahmouda, b*, Shuhymee Ahmada, Donny Abdul Latief Poespowidjojo ${ }^{a}$ \\ ${ }^{a}$ College of Business, Universiti Utara Malaysia, 06010 Changlun, Kedah, Malaysia \\ ${ }^{b}$ Department of Business Administration, Northwest University Kano, Nigeria \\ *Corresponding author: ahmad_mahmoud@oyagsb.uum.edu.my
}

Article history: Received: 30 Julai 2017 Received in revised form: 05 Julai 2018 Accepted: 1 August 2018 Published online: 31 August 2018

\begin{abstract}
Though a substantial number of researches have been documented between psychological safety, psychological empowerment and individual level performance, the manner through which these relationships transpires is scarcely studied, principally as regards to individual performance of middle managers in medium enterprises. To address this shortfall and to expound further on these relationships, several researchers proposed mediating variables to better explain the relationship between these variables. Accordingly, this paper proposes intrapreneurial behavior as a mediating variable on the psychological safety, psychological empowerment and individual level performance relationships of middle managers in Nigerian medium enterprises. Psychological safety, psychological empowerment and intrapreneurial behavior relationships have been deliberated, followed by the intrapreneurial behavior and middle manager successful performance relationship and lastly the proposed mediating role of intrapreneurial behavior on the psychological safety, psychological empowerment and individual level performance relationships.
\end{abstract}

Keywords: Psychological safety; psychological empowerment; intrapreneurial behavior; individual performance; middle managers; Nigeria.

\begin{abstract}
Abstrak
Walaupun sejumlah penyelidikan yang banyak telah didokumenkan antara keselamatan psikologi, pemerkasaan psikologi dan prestasi individu, cara yang dihubungkan oleh hubungan ini jarang dikaji, terutamanya mengenai prestasi individu pengurus pertengahan dalam perusahaan sederhana. Untuk menangani kekurangan ini dan untuk menerangkan hubungan ini lebih lanjut, beberapa penyelidik mencadangkan pemboleh ubah pengantara untuk menjelaskan hubungan antara pembolehubah ini dengan lebih baik. Oleh itu, kertas kerja ini mencadangkan tingkah laku intrapreneurial sebagai pemboleh ubah pengantara mengenai keselamatan psikologi, pemberdayaan psikologi dan hubungan prestasi tahap individu pengurus pertengahan di perusahaan sederhana Nigeria. Keselamatan psikologi, pemberdayaan psikologi dan hubungan tingkah laku intrapreneurial telah dibincangkan, diikuti oleh tingkah laku intrapreneurial dan pengurus pertengahan prestasi prestasi yang berjaya dan akhirnya peranan yang diusulkan peranan tingkah laku intrapreneurial terhadap keselamatan psikologi, pemberian psikologi dan hubungan prestasi tahap individu.
\end{abstract}

Kata kunci: Keselamatan psikologi; pemberdayaan psikologi; tingkah laku intrapreneurial; prestasi individu; pengurus pertengahan; Nigeria

(C) 2018 Penerbit UTM Press. All rights reserved

\subsection{INTRODUCTION}

The deplorable performance of individual employees and managers has been a fundamental challenge that linger at SMEs (Thompson, 2017). Just less than $50 \%$ of the workforce score their managers great on performance (Watson, 2012). Precisely poor performance has been a general challenge to managers of both private and public sectors in the Nigerian context (Bello 2012; Inuwa 2016), this is also more pronounced on Medium Enterprise (MEs) middle managers (Mahmoud, Ahmad, and Poespowidjojo 2018). However, the general performance of organizations depends heavily on the successful performance of their managers (Ermalina, Hendriani, \& Efni, 2017; Ghaffari, Shah, Burgoyne, Nazri, \& Salleh, 2017; June, Kheng, \& Mahmood, 2013). Thus, most of the MEs in Nigeria are functioning lower than their average capacity (SMEDAN, 2013). With the rock-hard competition and deplorable managerial capacities fronting MEs in Nigeria (Agwu, 2014; Onugu, 2005), managers and employees that perform greatly are important in facing these challenges (Jyoti \& Dev, 2017). Propitiously, intrapreneurial behavior (IB) is capable of enhancing the individual performance of managers (Ahmad, Nasurdin, \& Zainal, 2012; Bakar \& Mahmood, 2014; Bakar, Mahmood, Ramli, \& Saad, 2016).

Like other management field, entrepreneurship could be studied at the organizational level, individual level (Bosma, Stam, \& Wennekers, 2010; Mair, 2005; Valsania, Moriano, \& Molero, 2016; Wakkee, Elfring, \& Monaghan, 2010) and even macro level (Bosma et al., 2010). But, interest in the individual level of analysis for the intrapreneurial behavior has been increasingly favored by scholars (Joardar \& Wu, 2011). The individual level IB is accepted as an essential component for the performance success of managers (Ahmad et al., 2012; 
Fellnhofer et al., 2016) and economic progression within establishments (De Jong, Parker, Wennekers, \& Wu, 2011). However, employees and managers that perform exceedingly well towards organizational goals are necessarily needed to achieve competitive advantage (Sonnentag \& Frese, 2002). Since entrepreneurial organizations emerge from the IB of employees, it is therefore indispensable for researchers to examine the individual rather than the organizational level IB (Stewart, 2009).

Yet, IB remain inadequate in countries that are developing, but predominant in countries that are developed (Bosma et al., 2013). Intrapreneurs are prevalent about twice in the high income economies than the low income economies, this is divergent to early start-ups that are more copious in the low income economies (Bosma et al., 2010). Global Entrepreneurship Monitor (GEM) revealed that, the factor driven economies have the least intrapreneurial employees with only $0.4 \%$ of the adult population been intrapreneurial employees, the efficiency driven economies have $2.3 \%$, and the innovation driven economies have the largest though inadequate figure of $5.8 \%$ of employees in the preceding three years based on GEM broad definition (Bosma et al., 2013). Nigerian economy is identified to be in transition from the factor to the efficiency driven economy (World Economic Forum, 2015). Hence, Nigeria is among the economies that has dearth intrapreneurial activities, and this necessitate the requirement to investigate factors that accelerate and inspire IB within the labor force.

Previous researchers placed a profuse enunciation on the organizational level factors that prompt IB (Antoncic \& Hisrich, 2003; Rigtering \& Weitzel, 2013; Van der Sijde, Veenker, \& During, 2013), however limited studies acknowledged the impact of individual psychological factors that impacts the IB of middle managers. Studies that concerted on individual influences that inspire IB comprises the psychological ownership and job satisfaction (Mustafa, Martin, \& Hughes, 2016), psychological empowerment and perceived organizational support (Hashemi, Nadi, Hosseini, \& Rezvanfar, 2012), employee motivation and individual ability (Moshtaghi, Moridi, Farokhi, Konani, \& Rotafi, 2012), demographic influences (Serinkan, Kaymakçi, Arat, \& Avcik, 2013), and dispositional traits (Holt, Rutherford, \& Clohessy, 2007; Zampetakis, Beldekos, \& Moustakis, 2009). Various researchers accepted the significance of psychological factors on IB (Pradhan \& Nath, 2012). Likewise, various researchers requested for supplementary researches on the psychological factors that influence IB (see for instance, Boon et al., 2013; Park, Kim, \& Krishna, 2014; Taştan \& Güçel, 2014).

Auspiciously, psychological safety and psychological empowerment are proposed to bolster the intrapreneurial behavior and performance, this assertion has been affirmed by the previous literature. For instance, psychological safety was found to be related with the facets of IB by many researchers (Edmondson \& Lei, 2014; Frazier et al., 2016; Liang, Farh, \& Farh, 2012), psychological empowerment was also found to influence IB (Hashemi et al., 2012; Park et al., 2014; Struzyna \& Marzec, 2003; Stull, 2005), and IB was found to influence the performance of managers (Bakar et al., 2016; Ahmad et al., 2012; Fellnhofer et al., 2016).

\section{Research Objective}

The individual level intrapreneurial behavior is recognized as an essential component for the performance success of managers (Ahmad et al., 2012; Fellnhofer et al., 2016) and economic progression within establishments (De Jong, Parker, Wennekers, \& Wu, 2011). Thus, the objective of this paper is to consider the individual level of analysis for the intrapreneurial behavior of middle managers which is not as widely researched as the organizational level analysis (corporate entrepreneurship). Another important objective of this study is to propose the mediating effect of intrapreneurial behavior on the relationship between psychological safety and psychological empowerment on the individual performance of middle managers.

\subsection{LITERATURE REVIEW}

\section{Middle Manager Individual Performance (MIP)}

The performance of individual managers and employees is a requisite outcome in several research fields, and practice (Koopmans et al., 2014). Much of the staff selection procedures are fabricated on the ground of picking job applicants that stand more likely to reach a superior performance (Viswesvaran \& Ones, 2000).

The combination of results, successes, grades and values that have been attained in work is referred to as individual performance (Jalalkamali, Ali, Hyun, \& Nikbin, 2016). Performance is the amount of success that was attained by an individual manager or employee in undertaking his individual job and responsibilities (Daniel, \& Purwanti, 2015). It is also referred to the expected value of individual actions that are apposite to furthering the success of organizations (Tabiu, Pangil, \& Othman, 2016). Individual performance covers the task performance, contextual performance (Koopmans et al., 2014; Koopmans et al., 2014; Koopmans et al., 2011; Motowidlo, Borman, \& Schmit, 1997) and the counterproductive behavior (Koopmans et al., 2014; Koopmans et al., 2014; Koopmans et al., 2011; Viswesvaran \& Ones, 2000). But the combination of task and contextual performance only (Borman \& Motowidlo, 1997; Motowidlo et al., 1997) are considered more appropriate for the current study (Husin, Yaakub, \& Malek, 2014; Mustapa \& Mahmood, 2016).

Since, the middle managers are held liable for the technical, staffs, organizational operations and concerns (Yang, Zhang, \& Tsui, 2010), they are important in the intrapreneurship process (Burgess, 2013; Kuratko \& Goldsby, 2004; Mustafa et al., 2016), and their individual performance is also important for the general success of their firms (Akinyele, 2007; Taiwo, 2010).

\section{Intrapreneurial Behavior (IB)}

Intrapreneurial Behavior is a voluntary and uncompelled behavior (Valsania et al., 2016), which is attendant to the individual level of analysis and a bottom-up technique for offering proactive initiatives by individual managers or employees (Åmo, 2010; Bosma et al., 2010). Intrapreneurial behavior could be crucial to the long-term survival of organizations and the economy at large, it is therefore essential to expedite the study of intrapreneurial behavior in the under-studied developing economies (Madu \& Urban, 2014). Nonetheless studies on the intrapreneurial behavior of middle managers are scarce (Mustafa et al., 2016) in medium enterprises and particularly in the developing economies. 
Intrapreneurial Behavior is a strategic individual-level behavior that was rooted from the strategic organizational-level behavior conception of entrepreneurial orientation, which serves as an essential resource for opportunity exploitation (Covin \& Slevin, 1991; Lumpkin \& Dess, 1996) and growing middle managers individual performance (Bakar \& Mahmood, 2014; Bakar et al., 2015; Guth \& Ginsburg, 1990). Intrapreneurial behavior is the predisposition of the workforce to accept and practice entrepreneurial comportments through their risk taking, pro-activeness and innovativeness inclinations (Stewart, 2009). Intrapreneurial behavior is a unidimensional construct the entails the total of three dimensions which consist risk taking, pro-activeness and innovativeness (Bakar \& Mahmood, 2014). Innovativeness is the proclivity to support new ideas and engage in creative process, experimentation and novelty that could leads to new processes or new products, while pro-activeness signifies the stance for anticipating and acting on forthcoming needs and wants to take advantage of opportunities, but risk-taking denotes to a propensity of taking steps to venture with through indeterminate outcomes (Bakar et al., 2015; Lumpkin \& Dess, 1996).

\section{Psychological Safety (PS)}

Psychological safety rouses the spirit of vitality and impacts the involvement of managers or employees in creative exertions (Kark \& Carmeli, 2009) and furthers the proclivity to offer actions and ideas to a shared organization (Edmondson \& Lei, 2014). PS indicates the beliefs of individual middle manager on the manner to which their colleagues and superiors will respond in the event of the introduction of new innovative ideas, questions, feedback request, or blunder reporting. The middle manager or employee calculates the relational concerns of this bearings, i.e. whether he will be reprimanded by organizational members for initiating an innovative idea (Edmondson et al., 2004). Psychological safety may be used as team level or individual level construct (Baer \& Frese, 2003).

PS climate signifies the informal procedures and the formal procedures that guide and supports a trustful and uncluttered in-house work relations. Therefore, a psychologically safe environment is defined as the atmosphere of work where managers and employees find it safe to voice their opinion without being proscribed or castigated (Baer \& Frese, 2003). Psychological safety was also defined by Edmondson (1999) Edmondson (1999) as a common belief for safety in undertaking relational risks by members of a particular team which later influence the team performance. Psychological safety is similarly defined as the staff capacity to prove and engage one's self without grief of unreceptive concerns to career, position or personal-image, (Kahn, 1990). The work atmosphere that is benign for risk taking and self-expression would amplify the execution and espousal of novelties, hence serving as an essential exigency to growing the broad potentials for innovation (Baer \& Frese, 2003).

\section{Psychological Empowerment (PE)}

Psychological Empowerment is described as the psychosomatic relationships between employees and the employer (Liu, Chiu, \& Fellows, 2007). Psychological Empowerment is also referred to the motivational conception of self-efficacy that is concerned with enabling instead of delegating (Conger \& Kanungo, 1988). Enabling the managers or workers denotes to the crafting of conditions which will deepen task achievement motivation by nurturing a sturdy personal efficacy feeling, whereas 'delegating' is only a solitary set of the circumstances that may perhaps empower or enable managers or employees (Conger \& Kanungo, 1988). PE is also the magnitude to which a manager or employee has the credence to possess work decisions control, work-related ability, and develop a sense of impact and meaning from work (Liden, Wayne, \& Sparrowe, 2000).

Equally, PE is in entirety described as a state of intrinsic motivation or a motivational notion that was established in four appending cognition sets: meaning, competence, self-determination and impact that make employees or managers to have a sense of job control (Spreitzer, 1995). Likewise, PE was demarcated as 'the cognitive state characterized by a sense of perceived control, competence, and goal internalization' (Menon, 1999 pp161-162). However, the PE incorporates both environmental and individual components (Ergeneli, Ari, \& Metin, 2006).

According to Thomas and Velthouse (1990), PE is multidimensional and thus a solitary notion cannot echo its quintessence. The four dimensions of PE are meaning and competence which corresponds with self-efficacy (Conger \& Kanungo, 1988), self-determination and impact (Thomas \& Velthouse, 1990). The nonappearance of any of this PE dimensions will dampen the overall amount of PE, albeit not totally eliminate it, thus the combination of this entire dimensions yields the complete construct (Spreitzer, 1995). Therefore, the four dimensions of PE suggest a "nearly complete or sufficient set of cognitions" for appreciating the concept of PE (Thomas \& Velthouse, 1990). While Menon (1999) proposed just three PE dimensions i.e. goal internalization, perceived control and competence, these three dimensions are more parallel to (Spreitzer, 1995). Notwithstanding, the four PE dimensions (Spreitzer, 1995), persist to be the most extensively validated that can be compressed in to a unitary construct (Seibert, Wang, \& Courtright, 2011).

\section{Social Exchange Theory (SET)}

Social exchange is described as the "cooperation between two or more individuals for mutual benefit" that can influence the performance of individuals (Cosmides \& Tooby, 1989 p52). The informal exchange processes within institutions are best pronounced by the SET (Emerson, 1976), which has to do with the mutual relationship between an organization and its workforce. The SET depends on reciprocity and trust which is bounded by the exchange relationship and expectancies for the performance of a second party, conveyed often on a priori and connected to relational treatment and outcome expectations (Rousseau, 1989). Equally, the SET is grounded on the reciprocal exchanges between one party and another (Cosmides \& Tooby, 2015). Rigtering and Weitzel (2013) specified that the progressions of SET are designated by hesitant (impending) benefits and the incapability to (lawfully) force the other party to undertake its onuses (Blau, 1967).

In addition to the role of external surroundings, the adoption of IB also requires the management to accentuate on pledging an effective social relations through the organization (De Clercq, Dimov, \& Thongpapanl, 2010). In IB research the SET accentuates that the workforce actions and decisions are to be observed in a relational angle; where the relationship between management and the workforce is of explicit value, mutual trust between the parties is at the focal point of this exchange association (Rigtering \& Weitzel, 2013). Trust is concerned with our faiths that a particular person or party will not at minimum mistreat or unleash a withering behavior on us directly or 
indirectly (Gambetta, 2000). Since IB is concomitant with taking risks, trust remains an imperious condition for IB portrayal (Dess et al., 2003; Rigtering \& Weitzel, 2013).

Psychological Safety was established on the conception of trust (Edmondson et al., 2004). A psychologically safe manager or employee is expected to be innovative, risk taking, pro-active, and more plausible to return the safety (trust) given to him with greater IB and performance IP. Accordingly, PS has to do with the degree of trust that a manager or employee relishes from colleagues, top management or any other (Edmondson et al., 2004). Moreover, some PE dimensions such as autonomy/self-determination and impact require the existence of trust in order to manifest. For instance, self-determination is described as the autonomy or liberty in initiating and advancing work methods and behaviors such as determining the work techniques, effort, and stride (Bell \& Staw, 1989; Spector, 1986). Therefore, when the top management lack trust on their middle managers or their workforce, the perceived autonomy/self-determination or impact may not exist; and therefore, PE would be weakened. Since the social exchanges are indispensable for the capability of organizations to amass knowledge, SET can encourage prosperous IB within organizations (De Clercq et al., 2010). On the other hand, middle managers or their workforces will decline to offer intrapreneurial ideas when the trust between them and the upper management is lacking, Intrapreneurial Behavior could thus be deliberated as an informal organizational progression that may be deepened by growing the PS and PE of middle managers, which would result to superior Individual Performance of the middle managers in line with the SET.

\section{Relationship Between Research Variables}

Psychological safety has in recent times developed into a significant academic and practical concern, due to the protracted impact of innovation and learning within firms in our time (Edmondson \& Lei, 2014). Thus, firms that afford a PS atmosphere will magnify and drive the potentials of creative managers or employees and their learning comportment (Baer \& Frese, 2003). The climate of psychological safety facilitates in explicating why employees or their managers express their ideas for organizational growth (Detert \& Burris, 2007; Liang, Farh, \& Farh, 2012), and chase the ingenuity to develop novel products (Baer \& Frese, 2003), expedite the performance of teams and organizations (Baer \& Frese, 2003; Edmondson et al., 2004; Schaubroeck, Lam, \& Peng, 2011). In summation, organizations were PS subsists, accelerates the taking of risk, divergent thinking, creativity, and rouses exploratory learning and exploitative engagement (Choo, Linderman, \& Schroeder, 2007; Edmondson, 2003; Edmondson \& Lei, 2014). The emotional state of vitality is driven by PS, which also impact on the creative contribution of the employee (Kark \& Carmeli, 2009).

The workforce tends to be more creative, proactive, and offer more fruitful ideas when the climate of psychological safety exists (Edmondson et al., 2004). Work settings that assure coordination and safety between workfellows have an affirmative significant association with IB (Rojuaniah, Sule, \& Joeliaty, 2016). One of the three PS components is the perceived support of management (Brown \& Leigh, 1996) which has a significant impact on IB (Ahmad et al., 2012; Hornsby, Kuratko, Shepherd, \& Bott, 2009; Hornsby, Kuratko, \& Zahra, 2002; Kuratko, Montagno, \& Hornsby, 1990). Likewise, PS has a significant positive relationship with pro-activeness (Frazier et al., 2016), which is one of the components of IB (Covin \& Slevin, 1991; Katharina Fellnhofer et al., 2016). However, PS has a significant impact on the workforce creativity (Frazier, Fainshmidt, Klinger, Pezeshkan, \& Vracheva, 2016; Gong, Cheung, Wang, \& Huang, 2012; Koopmann, Lanaj, Wang, Zhou, \& Shi, 2016; Liu, Zhang, Liao, Hao, \& Mao, 2016). Thus, it is postulated that:

H1- Psychological Safety would have a significant positive relationship with Intrapreneurial Behavior.

Intrapreneurial Behavior avows the creativity, innovation, and employee initiatives, thus, psychological empowerment and its panorama to rejuvenate the workforce has imperative role in IB studies (Stull, 2005). Since employees that feel empowered has a particular belief of having work autonomy and impact, they would plausibly be creative; with a lesser amount of inhibited feeling compared to other staffs by technical work aspects or rule-bound (Amabile, 1988). Moreover, the feeling of self-efficacy which is attributed to empowered employees would make them more plausible to be inventive in the process of accomplishing their tasks with likely success (Amabile, 1988; Redmond, Mumford, \& Teach, 1993).

The relationship between PE and individual flexibility was suggested to effect innovative behavior (Thomas \& Velthouse, 1990). The covenant with creative drive has been associated with intrinsic motivators (PE components) such as self-determination and meaning (Amabile, 1988), likewise, impact and competence would probably advance the capability of employees to implement their ideas and transformation proposals, which would result to greater and improved innovation (Seibert et al., 2011). When employees are confident on their PE perception, they will comprehend their occupation as meaningful, have confidence in their ability to adeptly perform, they would be further equipped to dwell their effort in devoting resources, hunting for information, and crafting the alternatives to wrestle work-related snags, and are expected to be more creative (Zhang \& Bartol, 2010).

PE has an affirmative significant association with innovative behavior (Seibert et al., 2011; Spreitzer, 1995). Equally, PE has an inextricable correlation with innovative behavior in entrepreneurial establishment case studies (Kanter, 1984). However, PE was reported to influence the workforce creativity (Alge, Ballinger, Tangirala, \& Oakley, 2006; Zhang \& Bartol, 2010). PE has a significant relationship with IB on the direct PE-IB path, prior to the toting of other paths that are also direct (Stull, 2005). Correspondingly, Hashemi et al. (2012) conveyed that PE is associated with IB. Compatibly, PE was associated with IB through mediation of some variables (Hashemi et al., 2012; Park et al., 2014). The entire dimensions of PE reported a significant relationship with IB dimensions (Struzyna \& Marzec, 2003), some studies also reported similar findings which reinforce the impending PE influence on IB (Stull, 2005). Among the four PE dimensions for instance; competence/self-efficacy (Markman \& Baron, 2003) and autonomy (Lumpkin \& Dess, 1996) were associated with IB. The competence dimension of PE likewise appears to affect the taking of more risk (Heath \& Tversky, 1991) and impact the perceptions of threats and opportunities (Krueger \& Dickson, 1994), these notions are often closely concomitant with IB (Stull, 2005). Therefore, this study posits that:

H2- Psychological Empowerment would have a positive significant relationship with Intrapreneurial Behavior.

Competitive pressure and market fragmentations, pro-activeness, innovativeness and risks taking are found to be a requisite too for greater performance of managers (Bakar et al., 2016). Leaders or managers perform better when they act entrepreneurially (Antoncic \& Zorn, 2004; Bakar et al., 2015, 2016; Stewart, 2009). Since the middle managers function as leaders, their intrapreneurial behavior and successful individual performance is precisely indispensable in thrilling the performance of organizations and their workforce (Bakar et al., 2016). Likewise, the development of valuable innovative ideas (Amabile, 1988), is positively linked to the performance of individuals (Gong, Huang, \& Farh, 2009). In the fast changing global competitive market atmosphere, it would be difficult for managers to perform 
effectively without adopting innovative, proactive and risk taking behaviors. The innovativeness and pro-activeness of managers, are affirmative ingredients to attaining competitive advantage and greater performance. Therefore, the intrapreneurial behavior has now become a necessity for managers to perform.

Intrapreneurial behavior was found to have a positive relationship with the individual performance of managers and their perceived organizational performance (Fellnhofer el., 2016). Similarly, many researchers have reported a positive relationship between intrapreneurial behavior and individual performance managers and employees (Ahmad et al., 2012; Bakar \& Mahmood, 2014; Bakar et al., 2016; Ismail, Mahmood, \& Ab Rahim, 2012; Mahmoud et al., 2018; Stewart, 2009: Uslu, Eryiğit, \& Çubuk 2015).

H3- Intrapreneurial Behavior would have a significant positive relationship with Individual Performance.

Having presented the existence of relationships between the study variables, this paper reasons that intrapreneurial behavior could act as a mediator between psychological safety, psychological empowerment and their relationship with individual performance of middle managers. Meaning that, the relationship between psychological safety, psychological empowerment and individual performance will be better explained when the intrapreneurial behaviour is introduced to the relationship. Specifically, the mediator is a variable that intervene and acts as a conduit over which the independent variable is capable of influencing the dependent variable (Baron \& Kenny, 1986; Hayes, 2009). The reviewed literature indicates the existing relationship between psychological safety and psychological empowerment on the intrapreneurial behaviour, and also the prevailing relationship between intrapreneurial behaviour and individual performance. In fulfilment to the mediation conditions by Hayes (2009), the intrapreneurial behaviour can therefore, serve as a mediator on the relationship between psychological safety and psychological empowerment to individual performance. Thus, it is proposed that:

H4- Intrapreneurial Behavior would mediate the relationship between psychological safety and Individual Performance.

H5- Intrapreneurial Behavior would mediate the relationship between psychological empowerment and Individual Performance.

\subsection{CONCEPTUAL FRAMEWORK}

Based on the above deliberations, it is conspicuous that psychological safety and psychological empowerment could strongly affect intrapreneurial behavior. Equally, the intrapreneurial behavior also demonstrates a strong influence on the individual performance of middle managers. According to Hayes (2009) the mediating variable must be related to the dependent variable, and that the independent variables must at the same time relate to the mediator variable. Unlike Baron and Kenny (1986) that necessitates the existence of a direct relationship between the independent variable(s) and the dependent variable(s) as a precondition for mediation, Hayes (2009) substantiate and proves that the direct relationship between the independent variables and the dependent variable is not a necessary precondition for mediation. Thus, figure 1 below depicts the proposed conceptual framework for this study.

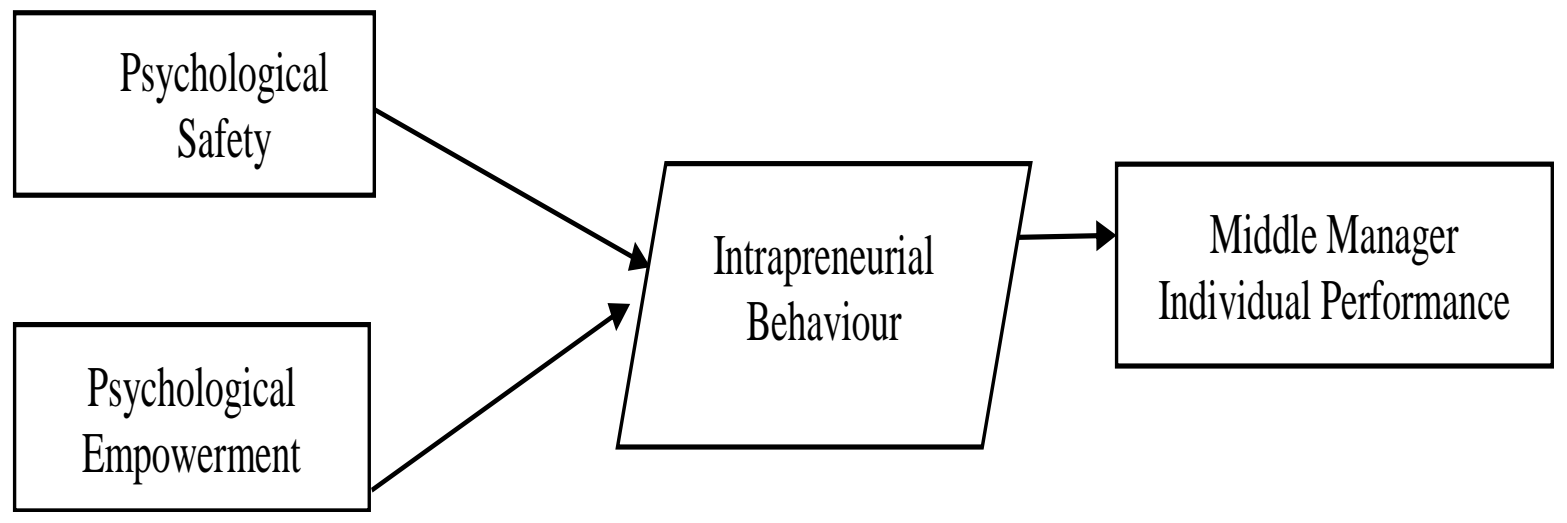

Figure 1 Conceptual research framework

\subsection{CONCLUSION}

This paper deliberated the possible mediating effect of intrapreneurial behavior on the relationship between psychological safety, psychological empowerment and the individual performance of middle managers in Nigeria. The preceding literature was examined concerning the relationship of intrapreneurial behavior with individual performance, psychological safety, and psychological empowerment. The effects of the association between psychological safety and psychological empowerment with individual performance was also scrutinized. Based on this, it was argued that intrapreneurial behavior will play a substantial role in mediating the association between psychological safety, psychological empowerment and individual performance of middle managers in the context of Nigeria, particularly in the medium enterprises. It is also anticipated that the existence of intrapreneurial behavior would provide better explanation of the direct and indirect effects of the association between psychological safety, psychological empowerment and individual performance of Nigerian middle managers of MEs. On this note, it is imperative for the Nigerian middle managers to behave intrapreneurially and to have a climate that encourage psychological safety and psychological empowerment at work in order to improve their to individual performance. 


\section{References}

Agwu, M. O. (2014). Issues, Challenges And Prospects Of Small And Medium Scale Enterprises (SMEs) in Port-Harcourt City. European Journal of Sustainable Development, 3(1), 101-114. http://doi.org/10.14207/ejsd.2014.v3n1p101

Ahmad, N., Nasurdin, A., \& Zainal, S. (2012). Nurturing Intrapreneurship To Enhance Job Performance: The Role Of Pro-Intrapreneurship Organizational Architecture. Journal of Innovation Management in Small and Medium Enterprise, 2012, 1-9. http://doi.org/10.5171/2012.868880

Akinyele, S. T. (2007). A Critical Assessment Of Environmental Impact On Workers Productivity in Nigeria. Research Journal on Business Management, 1(1), 50-61.

Alge, B. J., Ballinger, G. a, Tangirala, S., \& Oakley, J. L. (2006). Information Privacy In Organizations: Empowering Creative And Extra Role Performance. The Journal of Applied Psychology, 91(1), 221-232. http://doi.org/10.1037/0021-9010.91.1.221

Amabile, T. M. (1988). A Model Of Creativity And Innovation In Organizations. Research in Organizational Behavior, 10, 123-167. http://doi.org/Article

Åmo, B. W. (2010). Corporate Entrepreneurship And Intrapreneurship Related To Innovation Behaviour Among Employees. International Journal of Entrepreneurial Venturing, 2(2), 144-158. http://doi.org/10.1504/IJEV.2010.034819

Antoncic, B., \& Hisrich, R. D. (2003). Clarifying the Intrapreneurship Concept. Journal of Small Business and Enterprise Development, 10(1), 7-24. http://doi.org/10.1108/14626000310461187

Antoncic, B., \& Zorn, O. (2004). The Mediating Role Of Corporate Entrepreneurship In The Organizational Support-Performance Relationship : An Empirical Examination. Management Global Transitions, 2(1), 5-14.

Baer, M., \& Frese, M. (2003). Innovation is Not Enough: Climates For Initiative And Psychological Safety, Process Innovations, And Firm Performance. Journal of Organizational Behavior, 24(1), 45-68. http://doi.org/10.1002/job

Bakar, M. S., \& Mahmood, R. (2014). Linking Transformational Leadership And Corporate Entrepreneurship To Performance In The Public Higher Education Institutions in Malaysia. Advances in Management \& Applied Economics, 4(3), 109-122.

Bakar, M. S., Mahmood, R., \& Lucky, E. O. (2015). The Mediating Role Of Intrapreneurial Orientation Between Leadership Style, Knowledge Sharing Behaviour And Performance Of Malaysian Academic Leaders: A Conceptual Framework. Sains Humanika, 4(1), 17-22.

Bakar, M. S., Mahmood, R., Ramli, A., \& Saad, R. M. (2016). Knowledge Sharing Behaviour And Performance Of Academic Leaders: Mediating Role Of Corporate Entrepreneurship. Middle-East Journal of Scientific Research, 24(6), 2028-2035. http://doi.org/10.5829/idosi.mejsr.2016.24.06.23624

Baron, R. M., \& Kenny, D. A. (1986). The Moderator-Mediator Variable Distinction In Social The Moderator-Mediator Variable Distinction In Social Psychological Research: Conceptual, Strategic, And Statistical Considerations. Journal of Personality and Social Psychology, 51(6), 1173-1182. http://doi.org/10.1037/0022-3514.51.6.1173

Bell, N. E., \& Staw, B. M. (1989). People as Sculptors Versus Sculpture: The Roles Of Personality And Personal Control In Organizations. In Handbook Of Career Theory, 232.

Bello, S. M. (2012). Impact of Ethical Leadership on Employee Job Performance. International Journal of Business and Social Science 3(11), 228-37.

Blau, P. M. (1967). Exchange and Power In Social Life. New York: John Wiley \& Sons Inc.

Boon, J., Van der Klink, M., \& Janssen, J. (2013). Fostering Intrapreneurial Competencies Of Employees In The Education Sector. International Journal of Training and Development, 17(3), 210-220.

Borman, W. C., \& Motowidlo, S. J. (1997). Task Performance And Contextual Performance: The Meaning For Personnel Selection Research. Human Performance, 10(2), 99-109. http://doi.org/10.1207/s15327043hup1002 3

Bosma, N., Stam, E., \& Wennekers, S. (2010). Intrapreneurship-An international study. EIM Research Report, 3-29.

Bosma, N., Wennekers, S., Marible, G., Amorós, J. E., Alona, M., \& Singer, S. (2013). Global Entrepreneurship Monitor: Special report on entrepreneurial employee activity. GEM, Global Entrepreneurship Research Association (GERA), 7-72.

Brown, S. P., \& Leigh, T. W. (1996). A New Look At Psychological Climate And Its Relationship To Job Involvement, Effort, And Performance. Journal of Applied Psychology, 81(4), 358-368. http://doi.org/10.1037/0021-9010.81.4.358

Burgess, C. (2013). Factors Influencing Middle Managers' Ability To Contribute To Corporate Entrepreneurship. International Journal of Hospitality Management, 32(1), 193-201. http://doi.org/10.1016/j.ijhm.2012.05.009

Choo, A. S., Linderman, K., \& Schroeder, R. G. (2007). Social and method effects on learning behaviors and knowledge creation in six sigma projects. Management Science, 53(3), 437-450.

Conger, J. A., \& Kanungo, R. N. (1988). The empowerment process: Integrating theory and practice. Academy of Management Review, 13(3), 471-482.

Cosmides, L., \& Tooby, J. (1989). Evolutionary psychology and the generation of culture, part II. Case study: A computational theory of social exchange. Ethology and Socio-biology, 10(1-3), 51-97. http://doi.org/10.1016/0162-3095 (89)90013-7

Cosmides, L., \& Tooby, J. (2015). Adaptations for Reasoning About Social Exchange. In the handbook of evolutionary psychology. (pp. 625-668).

Covin, J. G., \& Slevin, D. P. (1991). A Conceptual Model Of Entrepreneurship As Firm Behavior. Entrepreneurship Theory and Practice, 16(1), 7-25.

Daniel, F., \& Purwanti, A. (2015). The Impact Of Organizational Culture And Job Satisfaction To Organizational Commitment And Employees' Job Performance (An Empirical Study at A University in Tangerang). In Asia-Pacific Management Accounting Association (APMAA) Annual Conference At: Bali, Indonesia (pp. 1-18). http://doi.org/10.13140/RG.2.1.1196.4240

De Clercq, D., Dimov, D., \& Thongpapanl, N. T. (2010). The Moderating Impact Of Internal Social Exchange Processes On The Entrepreneurial OrientationPerformance Relationship. Journal of Business Venturing, 25(1), 87-103. http://doi.org/10.1016/i.jbusvent.2009.01.004

De Jong, J. P. J., Parker, S. K., Wennekers, S., \& Wu, C. (2011). Corporate Entrepreneurship At The Individual Level: Measurement and determinants. EIM Research Reports. Zoetermeer: EIM (Vol. 11)

Dess, G. G., Ireland, R. D., Zahra, S. A., Floyd, S. W., Janney, J. J., \& Lane, P. J. (2003). Emerging Issues In Corporate Entrepreneurship. Journal of Management, 29(3), 351-378. http://doi.org/10.1016/S0149-2063(03)00015-1

Detert, J. R., \& Burris, E. R. (2007). Leadership Behavior And Employee Voice: Is The Door Really Open? Academy of Management Journal, 50(4), 869-884.

Edmondson, A. (1999). Psychological Safety And Learning Behavior In Work Teams. Administrative Science Quarterly, 44(2), 350-383, http://doi.org/10.2307/2666999

Edmondson, A. C. (2003). Speaking Up In The Operating Room: How Team Leaders Promote Learning In Interdisciplinary Action Teams. Journal of Management Studies, 40(6), 1419-1452. http://doi.org/10.1111/1467-6486.00386

Edmondson, A. C., Kramer, R. M., \& Cook, K. S. (2004). Psychological Safety, Trust, And Learning In Organizations: A Group-Level Lens. Trust and distrust in organizations: Dilemmas and approaches, 12, 239-272.

Edmondson, A. C., \& Lei, Z. (2014). Psychological safety: The History, Renaissance, And Future Of An Interpersonal Construct. Annual Review of Organizational Psychology and Organizational Behavior, 1, 23-43. http://doi.org/10.1146/annurev-orgpsych-031413-091305

Emerson, R. M. (1976). Social Exchange Theory. Annual Review of Sociology, 2(1976), 335-362.

Ergeneli, A., Ari, G. S., \& Metin, S. (2007). Psychological Empowerment And Its Relationship To Trust In Immediate Managers. Journal of business research, 60(1), 41-49. http://doi.org/10.1016/j.jbusres.2006.09.012

Ermalina, Hendriani, S., \& Efni, Y. (2017). The Mediating Effect Of Work Enhusiasm On Non Financial Compensation And Style Of Leadership Implementation To Employee's Performance in PT. Instrucom, Riau, Indonesia. International Journal of Applied Business and Economic Research, 15(2), 1-11.

Fellnhofer, K., Puumalainen, K., \& Sjogren, H. (2016). Entrepreneurial Orientation And Performance - Are Sexes Equal ? International Journal of Entrepreneurial Behavior \& Research, 22(3), 346-374. http://doi.org/10.1108/IJEBR-12-2015-0286

Frazier, M. L., Fainshmidt, S., Klinger, R. L., Pezeshkan, A., \& Vracheva, V. (2016). Psychological Safety: A Meta-Analytic Review And Extension. Personnel Psychology, 70(1), 113-165. http://doi.org/10.1111/peps.12183

Gambetta, D. (2000). Can We Trust? In Trust: Making And Breaking Cooperative Relations, 13, 213-237. http://doi.org/10.1.1.24.5695 
Ghaffari, S., Shah, I. M., Burgoyne, J., Nazri, M., \& Salleh, J. R. (2017). The Influence Of Motivation On Job Performance: A Case Study At Universiti Teknologi Malaysia. Australian Journal of Basic and Applied Sciences, 11(4), 92-99.

Gong, Y., Cheung, S. Y., Wang, M., \& Huang, J. C. (2012). Unfolding the Proactive Process For Creativity: Integration Of The Employee Proactivity, Information Exchange, And Psychological Safety Perspectives. Journal of Management, 38(5), 1611-1633. http://doi.org/10.1177/0149206310380250

Gong, Y., Huang, J. C., \& Farh, J. L. (2009). Employee Learning Orientation, Transformational Leadership, And Employee Creativity: The Mediating Role Of Employee Creative Self-Efficacy. The Academy of Management Journal, 52(4), 765-778.

Hashemi, S. M. K., Nadi, H. K., Hosseini, S. M., \& Rezvanfar, A. (2012). Explaining Agricultural Personnel's Intrapreneurial Behavior: The Mediating Effects Of Job Satisfaction And Organizational Commitment. International Journal of Business and Social Science, 3(6), 299-308.

Hayes, A. F. (2009). Beyond Baron and Kenny: Statistical Mediation Analysis In The New Millennium. Communication Monographs, 76(4), 408-420. http://doi.org/10.1080/03637750903310360

Heath, C., \& Tversky, A. (1991). Preferences and Beliefs: Ambiguity And Competence In Choice Under Uncertainty. Journal of Risk and Uncertainty, 4(5), 5-28. http://doi.org/10.1007/BF00057884

Holt, D. T., Rutherford, M. W., \& Clohessy, G. R. (2007). Corporate Entrepreneurship: An Empirical Look At Individual Characteristics, Context, And Process Journal of Leadership \& Organizational Studies, 13(4), 40-54.

Hornsby, J. S., Kuratko, D. F., Shepherd, D. A., \& Bott, J. P. (2009). Managers' Corporate Entrepreneurial Actions: Examining Perception And Position. Journal of Business Venturing, 24(3), 236-247. http://doi.org/10.1016/j.jbusvent.2008.03.002

Hornsby, J. S., Kuratko, D. F., \& Zahra, S. A. (2002). Middle Managers' Perception Of The Internal Environment For Corporate Entrepreneurship: Assessing A Measurement Scale. Journal of Business Venturing, 17(3), 253-273. http://doi.org/10.1016/S0883-9026(00)00059-8

Husin, H., Yaakub, S., \& Malek, M. M. M. A. (2014). The Relationship Between Cultural Intelligence And Work Performance Of Public Service Workers In Malaysia. In Human Rights Disclosure: Before And After The Global Financial Crisis, 126-136.

Inuwa, M. (2016). Job satisfaction and employee performance: An Empirical Approach. The Millennium University Journal, 1(1), 90-103.

Ismail, N. N. H. N., Mahmood, R., \& Ab Rahim, R. (2012). The Relationship Between Intrapreneurial Orientation And Job Performance Among Academicians In Malaysian Public Universities. In ASEAN Entrepreneurship Conference, 91-100.

Jalalkamali, M., Ali, A. J., Hyun, S. S., \& Nikbin, D. (2016). Relationships Between Work Values, Communication Satisfaction, And Employee Job Performance: The Case Of International Joint Ventures In Iran. Management Decision, 54(4), 796-814.

Joardar, A., \& Wu, S. (2011). Examining The Dual Forces Of Individual Entrepreneurial Orientation And Liability Of Foreignness On International Entrepreneurs Canadian Journal of Administrative Sciences, 28(3), 328-340. http://doi.org/10.1002/cjas.203

June, S., Kheng, Y. K., \& Mahmood, R. (2013). Determining the Importance Of Competency And Person-Job Fit For The Job Performance Of Service Smes Employees in Malaysia. Asian Social Science, 9(10). http://doi.org/10.5539/ass.v9n10p114

Jyoti, J., \& Dev, M. (2017). Perceived High-Performance Work System And Employee Performance: Role Of Self-Efficacy And Learning Orientation Metamorphosis, 15(2), 1-18. http://doi.org/10.1177/0972622516688392

Kahn, W. A. (1990). Psychological Conditions Of Personal Engagement And Disengagement At Work. The Academy of Management Journal, 33(4), 692-724. http://doi.org/10.2307/256287

Kanter, R. M. (1984). The Change Masters. New York, Simon and Schuster.

Karimi, A., Malekmohamadi, I., Daryani, M. A., \& Rezvanfar, A. (2011). A Conceptual Model Of Intrapreneurship In The Iranian Agricultural Extension Organization Implications for HRD. Journal of European Industrial Training, 35(7), 632-657.

Kark, R., \& Carmeli, A. (2009). Alive and Creating: The Mediating Role Of Vitality And Aliveness In The Relationship Between Psychological Safety And Creative Work Involvement. Journal of Organizational Behavior, 30, 785-804. http://doi.org/10.1002/job

Koopmann, J., Lanaj, K., Wang, M., Zhou, L., \& Shi, J. (2016). Nonlinear Effects Of Team Tenure On Team Psychological Safety Climate And Climate Strength: Implications For Average Team Member Performance. Journal of Applied Psychology, 1-18. http://doi.org/10.1037/ap10000097

Koopmans, L., Bernaards, C. M., Hildebrandt, V. H., Lerner, D., de Vet, H. C., \& van der Beek, A. J. (2014). Construct Validity Of The Individual Work Performance Questionnaire. Journal of Occupational and Environmental Medicine, 56(3), 331-337. http://doi.org/10.3233/WOR-152237

Koopmans, L., Bernaards, C. M., Hildebrandt, V. H., Schaufeli, W. B., de Vet Henrica, C. W., \& van der Beek, A. J. (2011). Conceptual Frameworks Of Individual Work Performance: A Systematic Review. Journal of Occupational and Environmental Medicine, 53(8), 856-866. http://doi.org/10.1097/JOM.0b013e318226a763

Koopmans, L., Bernaards, C. M., Hildebrandt, V. H., Van Buuren, S., Van der Beek, A. J., \& De Vet, H. C. (2014). Improving the Individual Work Performance Questionnaire Using Rasch Analysis. Journal of Applied Measurement, 15(2), 160-. http://doi.org/10.1136/oemed-2013-101717.51

Krueger, N., \& Dickson, P. R. (1994). How Believing In Ourselves Increases Risk Taking: Perceived Self-Efficacy And Opportunity Recognition. Decision Sciences, 25(3), 385-400. http://doi.org/10.1111/j.1540-5915.1994.tb00810.x

Kuratko, D. F., \& Goldsby, M. G. (2004). Corporate Entrepreneurs Or Rogue Middle Managers? A Framework For Ethical Corporate Entrepreneurship. Journal of Business Ethics, 55(1), 13-30. http://doi.org/10.1007/s10551-004-1775-3

Kuratko, D. F., Montagno, R. V., \& Hornsby, J. S. (1990). Developing an Intrapreneurial Assessment Instrument For An Effective Corporate Entrepreneurial Environment. Strategic Management Journal, 11(Special Issue), 49-58.

Liang, J., Farh, C. I. C., \& Farh, J.-L. (2012). Psychological Antecedents Of Promotive And Prohibitive Voice: A Two-Wave Examination. Academy of Management Journal, 55(1), 71-92.

Liden, R. C., Wayne, S. J., \& Sparrowe, R. T. (2000). An Examination Of The Mediating Role Of Psychological Empowerment On The Relations Between The Job, Interpersonal Relationships, And Work Outcomes. Journal of Applied Psychology, 85(3), 407-416. http://doi.org/10.1037/0021-9010.85.3.407

Liu, A. M. M., Chiu, W. M., \& Fellows, R. (2007). Enhancing Commitment Through Work Empowerment. Engineering, Construction and Architectural Management, 14(6), 568-580. http://doi.org/10.1108/09699980710829021

Liu, W., Zhang, P., Liao, J., Hao, P., \& Mao, J. (2016). Abusive Supervision And Employee Creativity: The Mediating Role Of Psychological Safety And Organizational Identification. Management Decision, 54(1), 130-147.

Lumpkin, G., \& Dess, G. (1996). Clarifying The Entrepreneurial Orientation Construct And Linking It To Performance. Academy of Management Review, 21(1), 135172.

Madu, U. O., \& Urban, B. (2014). An Empirical Study Of Desired Versus Actual Compensation Practices In Determining Intrapreneurial Behaviour. South African Journal of Human Resource Management, 12(1), 1-10. http://doi.org/10.4102/sajhrm.v12i1.592

Mahmoud, M. A., S. B. Ahmad, and D. A. L. Poespowidjojo. (2018). Intrapreneurial Behavior, Psychological Safety And The Individual Performance Of Production/Operation Managers In Nigerian Medium Enterprises: Pilot test. Advanced Science Letters, 24(1): 423-425.

Mair, J. (2005). Entrepreneurial Behavior In A Large Traditional Firm: Exploring Key Drivers. In Corporate Entrepreneurship And Venturing , 49-72. Springer, Boston, MA. http://doi.org/10.1007/0-387-24850-1

Markman, G. D., \& Baron, R. A. (2003). Person-entrepreneurship Fit: Why Some People Are More Successful As Entrepreneurs Than Others. Human Resource Management Review, 13(2), 281-301. http://doi.org/10.1016/S1053-4822(03)00018-4

Menon, S. T. (1999). Psychological Empowerment: Definition, Measurement, And Validation. Canadian Journal of Behavioural Science, 31(3), 161-164. http://doi.org/http://dx.doi.org/10.1037/h0087084

Moshtaghi, S., Moridi, A., Farokhi, A., Konani, M., \& Rotafi, A. (2012). The Amount Of Corporate Entrepreneurship And Its Relationship With Performance Improvement Of Organizations. Journal of Basic and Applied Scientific Research, 2(5), 4361-4367.

Motowidlo, S. J., Borman, W. C., \& Schmit, M. J. (1997). A Theory Of Individual Differences In Task And Contextual Performance. Human Performance, 10(2), 7183. http://doi.org/10.1207/s15327043hup1002

Mustafa, M., Martin, L., \& Hughes, M. (2016). Psychological Ownership, Job Satisfaction, And Middle Manager Entrepreneurial Behavior. Journal of Leadership \& Organizational Studies, 1-16. http://doi.org/10.1177/1548051815627360 
Mustapa, A. N., \& Mahmood, R. (2016). Knowledge Management And Job Performance In The Public Sector: The Moderating Role Of Public Organizational Commitment. International Journal of Research in Business Studies and Management, 3(7), 28-36.

Onugu, B. A. N. (2005). Small and Medium Enterprises (Smes) In Nigeria: Problems And Prospects. (Unpublished Doctoral Dissertation). St. Clements University, Nigeria.

Park, S. H., Kim, J.-N., \& Krishna, A. (2014). Bottom-Up Building Of An Innovative Organization: Motivating Employee Intrapreneurship And Scouting And Their Strategic Value. Management Communication Quarterly, 28(4), 531-560. http://doi.org/10.1177/0893318914541667

Pradhan, R. K., \& Nath, P. (2012). Perception of Entrepreneurial Orientation And Emotional Intelligence: A Study On India's Future Techno-Managers. Global Business Review, 13(2010), 89-108. http://doi.org/10.1177/097215091101300106

Redmond, M. R., Mumford, M. D., \& Teach, R. (1993). Putting Creativity To Work: Effects Of Leader Behavior On Subordinate Creativity. Organizational Behavior and Human Decision Processes, 55(1), 120-151.

Rigtering, J. P. C., \& Weitzel, U. (2013). Work Context And Employee Behaviour As Antecedents For Intrapreneurship. International Entrepreneurship and Management Journal, 9(3), 337-360. http://doi.org/10.1007/s11365-013-0258-3

Rojuaniah, E., Sule, T., \& Joeliaty, S. (2016). The Factors Influence Intrapreneurship Behavior In Construction Company. International Journal of Scientific \& Technology Research, 5(5), 36-40.

Rousseau, D. M. (1989). Psychological and Implied Contracts In Organizations. Employee Responsibilities and Rights Journal, 2(2), 121-139. http://doi.org/10.1007/BF01384942

Schaubroeck, J., Lam, S. S. K., \& Peng, A. C. (2011). Cognition-Based And Affect-Based Trust As Mediators Of Leader Behavior Influences On Team Performance. The Journal of Applied Psychology, 96(4), 863-71. http://doi.org/10.1037/a0022625

Seibert, S. E., Wang, G., \& Courtright, S. H. (2011). Antecedents and Consequences Of Psychological And Team Empowerment In Organizations: A Meta-Analytic Review. Journal of Applied Psychology, 96(5), 981-1003. http://doi.org/10.1037/a0022676

Serinkan, C., Kaymakçi, K., Arat, G., \& Avcik, C. (2013). An Empirical Study On Intrapreneurship: In A Service Sector In Turkey. Procedia-Social and Behavioral Sciences, 89, 715-719. http://doi.org/10.1016/j.sbspro.2013.08.920

SMEDAN. (2013). SMEDAN and National Bureau Of Statistics Collaborative Survey: Selected Findings. Abuja, Nigeria.

Sonnentag, S., \& Frese, M. (2002). Performance Concepts And Performance Theory. Psychological Management Of Individual Performance, $23,3-25$.

Spector, P. E. (1986). Perceived Control By Employees: A Meta-Analysis Of Studies Concerning Autonomy And Participation At Work. Human Relations, 39(11), 1005-1016. http://doi.org/10.1177/001872678603901104

Spreitzer, M. (1995). Psychological Empowerment In The Workplace: Dimensions, Measurement, And Validation. The Academy of Management Journal, 38(5), $1442-1465$.

Stewart, J. K. (2009). An Investigation Of An Intrapreneurial Orientation Among Employees In Service Organizations (Doctoral Dissertation). The Ohio State University, USA.

Struzyna, J., \& Marzec, I. (2003). Multidimensional Empowerment As A Leverage For Shaping Entrepreneurial Behaviors: Some Empirical Evidence. Frontiers of Entrepreneurship Research, 2003: Babson College.

Stull, M. G. (2005). Intrapreneurship in Non-Profit Organizations: Examining The Factors That Facilitate Entrepreneurial Behavior Among Employees (Executive Doctor of Management Paper). Case Western Reserve University, Cleveland, Ohio, USA. http://doi.org/10.1017/CBO9781107415324.004

Tabiu, A., Pangil, F., \& Othman, S. Z. (2016). Examining the Link Between HRM Practices And Employees' Performance In Nigerian Public Sector. Management Science Letters, 6, 395-408. http://doi.org/10.5267/j.msl.2016.4.006

Taiwo, A. S. (2010). The Influence Of Work Environment On Workers Productivity: A Case Of Selected Oil And Gas Industry in Lagos, Nigeria. African Journal of Business Management, 4(3), 299-307. http://doi.org/ISSN 1993-8233

Taștan, S. B., \& Güçel, C. (2014). Explaining Intrapreneurial Behaviors Of Employees With Perceived Organizational Climate And Testing The Mediating Role Of Organizational Identification: A Research Study Among Employees Of Turkish Innovative Firms. Procedia-Social and Behavioral Sciences, 150, 862871. http://doi.org/10.1016/j.sbspro.2014.09.095

Thomas, K. W., \& Velthouse, B. A. (1990). Cognitive Elements Of Empowerment: An "Interpretive" Model Of Intrinsic Task Motivation. The Academy of Management Review, 15(4), 666-681.

Thompson, M. (2017). How to Manage Poor Employee Performance. Hearst Newspapers, LLC. Retrieved from http://smallbusiness.chron.com/manage-pooremployee-performance-44897.html

Towers Watson. (2012). Engagement at Risk: Driving Strong Performance In A Volatile Global Environment. Global Workforce Study. Retrieved from http://www.towerswatson.com/assets/pdf/2012-Towers-Watson-Global-Workforce-Study.pdf

Uslu, Tuna, Nimet Eryiğit, \& Çubuk, D. (2015). Individual and Organizational Effects Of The Corporate Practices With The Mediating Role Of Lean Intrapreneurship: Differences Between Public And Private Sector in Turkey. Procedia-Social and Behavioral Sciences, 210: 301-9. http://www.sciencedirect.com/science/article/pii/S1877042815057171

Valsania, S. E., Moriano, J. A., \& Molero, F. (2016). Authentic leadership and intrapreneurial behavior: Cross-level analysis of the mediator effect of organizational identification and empowerment. International Entrepreneurship and Management Journal, 12(1), 131-152. http://doi.org/10.1007/s11365-014-0333-4

Van der Sijde, P., Veenker, S., \& During, W. (2013). Intrapreneurship in SMEs: About the role of management and R\&D. European Journal of Business and Social Sciences, 1(11), 24-30.

Viswesvaran, C., \& Ones, D. S. (2000). Perspectives on Models Of Job Performance Perspectives On Models Of Job Performance. International Journal of Selection and Assessment, 8(4), 216-226. http://doi.org/10.1111/1468-2389.00151

Wakkee, I., Elfring, T., \& Monaghan, S. (2010). Creating entrepreneurial Employees In Traditional Service Sectors: The Role Of Coaching And Self-Efficacy. International Entrepreneurship and Management Journal, 6(1), 1-21. http://doi.org/10.1007/s11365-008-0078-Z

World Economic Forum. (2015). Global Competitiveness Report 2015 - 2016 (Vol. 1).

Yang, J., Zhang, Z. X., \& Tsui, A. S. (2010). Middle Manager Leadership And Frontline Employee Performance: Bypass, Cascading, And Moderating Effects. Journal of Management Studies, 47(4), 654-678. http://doi.org/10.1111/j.1467-6486.2009.00902.x

Zampetakis, L. A., Beldekos, P., \& Moustakis, V. S. (2009). Day-to-Day Entrepreneurship Within Organisations: The Role Of Trait Emotional Intelligence And Perceived Organisational Support. European Management Journal, 27(3), 165-175. http://doi.org/10.1016/j.emj.2008.08.003

Zhang, X., \& Bartol, K. M. (2010). Linking Empowering Leadership And Employee Creativity: The Influence Of Psychological Empowerment, Intrinsic Motivation, And Creative Process Management. Academy of Management Journal, 53(1), 107-128. http://doi.org/10.5465/AMJ.2010.48037118 